\title{
The Dangers of Female Mobility in Roman Imperial Times ${ }^{1}$
}

\author{
Margherita Carucci
}

\section{Introduction}

Recent work on mobility and migration in the Roman empire offers many useful insights into the dynamics of ancient travel, even though the subject of women and travel specifically has been addressed in only limited, albeit useful, ways. ${ }^{2}$ Though women's opportunities for stepping out of the house and travelling on a short or long journey were much more restricted and limited in range than those of the mobile man, Roman imperial women did travel more often than we used to think. Yet the image of the woman who centres her life on her family and restricts her daily activities to those within the domestic walls was an ideal that never lost its power and attraction in Roman society, even in imperial times, when the changing political and social circumstances gave especially upper-class women more opportunities for stepping into the more public (and male) sphere of politics and power.

The traditional ideal of domestic focus for Roman women is the framework within which senators were asked to evaluate the proposal that Aulus Caecina

1 I would like to thank the editors for their invitation to participate in this volume. I am most grateful to Rens Tacoma who helped to develop my argument with his insightful comments on earlier drafts of this paper. I also thank Miriam Groen-Vallinga for her helpful suggestions and stylistic improvements. Any remaining errors are my own.

2 See, for instance, the section 'Mobility' in E.A. Hemelrijk and G. Woolf, eds., Women and the Roman City in the Latin West (Leiden and Boston 2013) with contributions by Woolf 'Female mobility in the Roman West', 351-368, E.M. Greene, 'Female networks in military communities of the Roman West: A view from the Vindolanda tablets', 369-390, and L. Foubert, 'Female travellers in Roman Britain: Vibia Pacata and Julia Lucilla', 391-403; and also contributions in L. de Ligt and L.E. Tacoma, eds., Migration and Mobility in the Early Roman Empire (Leiden 2016): C. Bruun, 'Tracing familial mobility: Female and child migrants in the Roman West', 176-204, S. Hin, 'Revisiting urban graveyard theory: migrant flows in Hellenistic and Roman Athens', 234-263, L. Foubert, 'Mobile women in P. Oxy. and the port cities of Roman Egypt: Tracing women's travel behaviour in papyrological sources', 285-304, and L.E. Tacoma and R.A. Tybout, 'Moving epigrams: Migration and mobility in the Greek East', $345-389$. 
Severus made in the Senate in AD 21. In Annales 3.33-34, Tacitus reports that in the course of a debate in the Senate "Caecina proposed that no magistrate who had obtained a province should be accompanied by his wife." ${ }^{3} \mathrm{He}$ argued that

Haud enim frustra placitum olim, ne feminae in socios aut gentes externas traherentur; inesse mulierum comitatui quae pacem luxu, bellum formidine morentur et Romanum agmen ad similitudinem barbari incessus convertant. non imbecillum tantum et imparem laboribus sexum sed, si licentia adsit, saevum, ambitiosum, potestatis avidum.

Not without reason it was formerly agreed that women were not to be taken among our allies or into foreign countries; it is inherent to the train of women who delay peace through luxury and war with fear and who convert a Roman army on the march into the likeness of a barbarian procession. Women are not only feeble and unequal to hardship but, when they are not under control, also fierce, ambitious, and greedy of power.

Caecina's proposal was opposed by Valerius Messalinus, who argued that

neque enim, ut olim, obsideri urbem bellis aut provincias hostilis esse; et pauca feminarum necessitatibus concedi, quae ne coniugum quidem penates, adeo socios non onerent; cetera promisca cum marito nec ullum in eo pacis impedimentum. bella plane accinctis obeunda: sed revertentibus post laborem quod honestius quam uxorium levamentum?

Rome is not longer beset with wars, as in the past, nor are the provinces hostile. A few concessions were made to the women, but they were not a burden to their husbands' home, not even to our allies; in all other respects a woman who lived in intimacy with her husband was not an impediment to peace. Certainly wars require men ready to go and fight, but when they return home after their hardships, what is worthier than their wives' consolation?

Messalinus' rebuttal was supported by Drusus, who closed the debate with a few words on his own experience as a husband. After mentioning the precedent of Augustus, who had been often accompanied by his wife Livia when

3 Tac. Ann. 3.33: Severus Caecina censuit, ne quem magistratum cui provincia obvenisset uxor comitaretur. Translations are my own. 
he visited the provinces, Tiberius' son admitted his reluctance to be separated from the mother of his children if serving in foreign countries.

This debate as reported by Tacitus has raised much discussion among scholars. ${ }^{4}$ Here I would like to highlight the opposition between two different trends in Roman social attitudes towards women's mobility. Caecina's proposal reinforces the timeless value of the mos maiorum that was based on a rigid division of gender roles: men act in the public realm of politics and military while women perform their duties as devoted wives and good mothers inside the house. The speeches delivered by Messalinus and Drusus, by contrast, stress the importance of concordia between wife and husband: if political or military duties force a man to spend a long time away from his country, it is a wife's duty to leave the house and travel with her husband as his devoted companion. Drusus' mention of Augustus' practice of being accompanied by Livia on his travels, as well as the literary and epigraphic evidence, shows that women travellers had become a common feature of Roman social life in imperial times. ${ }^{5}$ Not surprisingly, Caecina's motion was defeated.

In the speeches reported by Tacitus the issue whether men travelling into foreign countries for their official duties should be accompanied by their wives is discussed from a restricted male perspective that takes into account only what is more advantageous for men. But if women had been admitted to the Senate and taken part in the discussion of matters that were important also for the female members of the society, what arguments would they have put forward? How would they have described from their point of view their own personal experience of accompanying the male members of their family on their travels? Since the topic of women travellers in the Roman empire is too broad to be discussed within the limits of a short article, the focus will be only on the negative impact that travelling may have had on Roman women. If, as Caecina

4 A.J. Marshall, 'Tacitus and the governor's lady: A note on Annals iii.33-4', Greece \& Rome 22.1 (1975), 11-18; A.J. Barrett, 'Aulus Caecina Severus and the military woman', Historia 54 (2005), 301-314 with previous bibliography. See also L. Foubert, 'The impact of women's travels on military imagery in the Julio-Claudian period', in O. Hekster and T. Kaizer, eds., Frontiers in the Roman World. Proceedings of the Ninth Workshop of the International Network Impact of Empire (Durham, 16-19 April 2009) (Leiden 2011), 349-361. The senatorial debate as reported by Tacitus is also analysed by L. Foubert, 'The lure of an exotic destination: the politics of women's travel in the early Roman empire', forthcoming, who discusses how women's travel threatened the socio-cultural hierarchy of the Roman upper class: I thank Dr Foubert for kindly giving me a copy of her manuscript.

5 For a list of wives or daughters who accompanied magistrates in the provinces, see M.-T. Raepsaet-Charlier, 'Epouses et familles de magistrates dans les provinces romaines aux deux premiers siècles de l'empire', Historia 31.1 (1982), 56-69. 
argues, women's travels had a negative impact on men, as they disrupted the military and political order created and supervised by the male upper-class, how might travel affect Roman women negatively? What were the real dangers that ancient women might have encountered when travelling? What risks to their physical and moral integrity did they perceive when embarking on a journey? In what follows I will try to shed some light on the dangers (real and perceived) of female mobility in the early Roman empire with a discussion of a selected number of literary and epigraphical references to risky journeys taken by women. Given the wide variety of forms in terms of space, time, and motivations that the term mobility encompasses (individuals may travel within the borders of a single province or move significant distances toward other provinces; they may plan to return home after a short journey or to settle down in a foreign country; they may voluntarily decide to embark on a journey or be compelled to leave home), here, for the purpose of my analysis, I will use the term mobility in a generic sense of movement outside the hometown, regardless of its permanent or temporary status or the motivations behind the journey.

Ancient written texts contain a huge amount of references to the dangers and hardships involved in travel, such as storms, piracy, and brigandage, which could affect either male or female voyagers. The perils of one's journeys were certainly a very exciting trope for the readers of ancient novels and poetry and a topic through which the writers of private letters or funerary inscriptions could demand attention and comfort. Very likely, nobody would have wished to read the monotonous details of a rapid and painless journey. The prevalence of anecdotes on dangerous journeys in Graeco-Roman literature and its narrative use may obscure the realities of ancient travel, which would be much safer and easier for most voyagers. Nevertheless, travel remained daunting and was a cause of anxiety at least in the perception and imagination of the majority.

The analysis of literary and epigraphic evidence specifically for women's mobility in Roman imperial times shows that the main danger travellers might have encountered on a sea-journey was shipwreck. A late fourth-century funerary inscription found at Autun, in Gaul, records the name of Eufronia, who had died in a shipwreck. ${ }^{6}$ Similarly, in an epitaph from Dalmatia, Maximus commemorates his young daughter Revocata, aged 8, who had died in a shipwreck

6 For the dangers of travelling by sea, see also Gambash, this volume. ECO $90=I L C V 1540=$ ICG 5 . 
together with her brother Hilarion, aged $4 \cdot{ }^{7}$ In a funerary inscription found at Rome, Iulius Secundus commemorates his wife Cornelia Tyche and his daughter Iulia Secunda, who probably died in the Iberian sea while sailing toward Spain:

Iam datus est finis vitae im/paussa malorum / vobis quas habet hoc gnatam / matremq sepulcrum / litore Phocaico pelagi vi / examinatas / illic unde Tagus et nobile / flumen Hiberus / forsum ortus vorsum occa/sus fluit alter et alter / stagna sub Oceani Tagus et / Tyrrhenica Hiberus

This is the end of your life, the end of sufferings for you, daughter and mother, who are buried in this grave. You two were exhausted by the violence of the sea on the Phocaean coast where Tagus starts and the famous river Hiberus ends and both flow the one into the Ocean and the other into the Tyrrhenian. ${ }^{8}$

Travel by ship did not necessarily end in death, but, undoubtedly, sea-voyages were fraught with perils. Iulia Maior, for instance, while following her husband Agrippa in his campaign in Asia minor, almost drowned on a night of heavy storms while trying to cross the flooded Scamander on her way to Ilium. ${ }^{9}$ The reality of potentially fatal accidents occurring during sea-journeys is reflected in the number of storms and shipwrecks that are described in the Greek and Latin fictional literature and poetry. In the elegiac poetry of the Augustan age, they became a literary trope that poets often used as a means to discourage their mistress from leaving. In Elegy 1.8.1-2, 5-8, Propertius deplores Cynthia's decision to sail toward Illyria and warns her from the rigours of travel that his mistress may not be able to face:

Tune igitur demens, nec te mea cura moratur?

an tibi sum gelida vilior Illyria?

...

tune audire potes vesani murmura ponti

7 CIL 3. $3107=I L C V$ 4360. Shipwreck may have been the cause of death for Victoria, aged 33, who is defined as tra(n)smarina ("beyond sea, coming from beyond the sea") in an epitaph found at Setif, in Algeria ( $C I L$ 8. $20414=I L C V$ 1476a). The fragmentary text does not allow us to know whether Victoria died at Setif, where she had moved, or during her sea journey to the African town.

8 CLE $436=$ CIL 6. 20674 .

9 Nicolaus of Damascus, Fragmente der Griechischen Historiker, 2 A: 421-2. 
fortis, et in dura nave iacere potes?

tu pedibus teneris positas fulcire pruinas, tu potes insolitas, Cynthia, ferre nives?

Are you then fool? Does not my anguish keep you here? Am I less to you than chilly Illyria?... Can you hear the roar of the furious seas and can you lie down on the hard ship bench? Can you press the hard planks with your tender feet? Cynthia, can you endure the unfamiliar snow?

In Amores 2.11. 9-12, 17-26, Ovid tries to discourage Corinna from her plan to go on a 'tricky voyage' by contrasting the dangerous waters to the safe shore:

quam tibi, me miserum, Zephyros Eurosque timebo et gelidum Borean egelidumque Notum! non illic urbes, non tu mirabere silvas; una est iniusti caerula forma maris. $\cdots$

et vobis alii ventorum proelia narrent; quas Scylla infestet, quasve Charybdis aquas; et quibus emineant violenta Ceraunia saxis; quo lateant Syrtes magna minorque sinu. haec alii referant ad vos; quod quisque loquetur, credite! credenti nulla procella nocet. Sero respicitur tellus, ubi fune soluto currit in inmensum panda carina salum; navita sollicitus cum ventos horret iniquos et prope tam letum, quam prope cernit aquam.

So much for you I, poor wretch, will fear Zephyros and Euros and the chilly Boreas and the cold Notum. There you will not marvel at either cities or woods; only the blue form of the cruel sea.... Let others tell you of the battles of the winds; of the waters that Scylla or Charybdis trouble; of the furious Ceraunia that stands out of the rocks; of Syrtes that are hidden in the big and small bay. Let others report it to you; whatever is said to you, believe! If you believe, no storm will harm you. Too late one looks back at the shore, when the ropes are loosed and the curved ship sails over the immense sea; while the worried sailor trembles at the adverse winds and sees clearly the water close as much as the death. 
The journeys planned by the Propertian Cynthia and the Ovidian Corinna are literary representations of travels that may be hypothetical or even dream-like. Nevertheless, the literary and epigraphic record of real sea-voyages shows that they may be fatal. Far from being only literary constructions opportunistically exaggerated by the poets in love, the dangers that a woman might have encountered on a ship were so real as to cause anxiety. In Elegy 2.26.1-4, Propertius projects into a dream his fears for Cynthia' safety during her sea-journey:

Vidi te in somnis fracta, mea vita, carina

Ionio lassas ducere rore manus, et quaecumque in me fueras mentita fateri,

nec iam umore gravis tollere posse comas

In my dreams I saw your boat broken in pieces and you, light of my life, to strike out with weary hands through the Ionian waves, and confess all the lies you have told me, unable to lift your hair weighed down with brine.

The risk of injuries or ill health was certainly higher during travels. In a private letter dated to the second century AD, Aphrodite writes to her sister Taonnophoris that while she was going to Alexandria, her foot was injured by a horse; the injury forced Aphrodite to delay her travel arrangements while her foot was being healed at great expense. ${ }^{10}$ Some women may have fallen ill in a foreign country and have died before being able to return home. In Confessions 9.10-11, Augustine recounts the death of his mother Monica at Ostia. On their way back to Africa from Milan, Augustine and his mother stopped at Ostia to rest after the fatigues of a long journey; five days later, she was prostrated by fever, lost conscience for some time, and died. ${ }^{11}$ Though Monica had originally wanted to be buried with her husband in Africa (a wish that was supported by her other son Navigius who said that he would be happier if she died in her own land rather than abroad), she later accepted to be buried at

$10 \quad B G U$ 13. 2350; R.S. Bagnall and R. Cribiore, Women's Letters from Ancient Egypt (Ann Arbor 2006), 366 .

11 For Monica, see also Tacoma, this volume. A further figure of a mother who died in a foreign country while following her son in his travels is Malthace. In the brief account reported by Flavius Josephus (J. AJ. 17.10.1), it is recorded that Herod the Great's wife fell ill and died in 4 BC in Rome, where she had travelled to accompany her son Archelaus who wanted to plead for his father's throne before Augustus. 
Ostia. ${ }^{12}$ Augustine's account of his mother's death in a foreign country reinforces the image of an exceptionally brave woman traveller but also confirms the perils of the ancient journey either by land or sea. In fact, earlier in the text, Augustine had recounted that Monica's first journey to Italy had not been without dangers, ${ }^{13}$ but she was able to comfort the sailors and assured them of a safe arrival:

iam venerat ad me mater pietate fortis, terra marique me sequens et in periculis omnibus de te secura. nam et per marina discrimina ipsos nautas consolabatur, a quibus rudes abyssi viatores, cum perturbantur, consolari solent, pollicens eis perventionem cum salute, quia hoc ei tu per visum pollicitus eras.

My mother had now come to me, resolute with piety, following me by land and sea and in all perils confiding in you. For in the dangers of sea she comforted even the sailors, by whom the inexperienced passengers, when alarmed, use to be comforted, assuring them of a safe arrival, because you had promised that to her by a vision.

This account enables Augustine to emphasise the superior character of his mother and the assurance of God's presence which has helped Monica to face hardship with courage and to calmly overcome the dangers of the sea. However, for the purposes of this paper, what is more interesting is Augustine's remark that the inexperienced voyagers usually go to the sailors for comfort when alarmed. The portrayal of the helpless and distressed traveller who in the moment of peril seeks moral comfort, suggests that in ancient perception travel was associated with dangers, hardship, and uncertainty.

Similarly, Seneca praises his aunt for her heroic behaviour during a seastorm while she was travelling with her husband:

Carissimum virum amiserat, auunculum nostrum, cui virgo nupserat, in ipsa quidem navigatione; tulit tamen eodem tempore et luctum et metum evictisque tempestatibus corpus eius naufraga evexit.

12 For a discussion of this passage and of the ancient practice of the repatriation of corpses, see R.A. Tybout, 'Dead men walking: the repatriation of mortal remains', in L. de Ligt and L.E. Tacoma, eds., Migration and Mobility in the Early Roman Empire (Leiden 2016), 390-437.

13 Aug. Conf. 6.1. I thank Rens Tacoma for pointing out this reference to me. Augustine does not specify what perils Monica encountered on her journey. 
In the midst of a sea-voyage, she had lost her dearest husband, to whom she got married when she was a maiden; nevertheless, she endured at the same time both grief and fear and overcoming the storm she, though shipwrecked, rescued his body. ${ }^{14}$

In Seneca's words, his aunt certainly showed very brave behaviour or perhaps did simply what was expected from a wife. In the very moment of high risk for her life, his aunt did not look at how she might escape from the wrecked ship but resolved to rescue her husband's body and give him a proper burial. ${ }^{15}$

A woman travelling to a foreign country away from the protective environment of the original family may also risk being killed by her closest relatives. Born to an elite family in Rome, Regilla moved to Greece in 138/9 when she married the politician and rhetorician Herodes Atticus, but when she was eight months pregnant, she died of a kick in her abdomen. Her husband was brought to trial in Rome on the charge of murder by Regilla's brother, but with the intercession of the emperor Marcus Aurelius, Herodes was exonerated and only his freedman Alcimedon was declared guilty. In her study of the murder of Regilla, Sarah B. Pomeroy states that "If Regilla had married a Roman, or at least if she had remained in Rome, her brother and other kinsmen and friends, and perhaps even Marcus Aurelius and Faustina, would have monitored her relationship with Herodes."16 I have argued in another article that a woman whose marriage was monitored by her kinsmen was not necessarily protected from a violent husband. ${ }^{17}$ However, Pomeroy's observation that "Regilla's isolation in Greece gave Herodes a de facto power over her"18 poignantly emphasises the high risks that travelling away from the protective environment of home may have for a woman.

Textual evidence attests to other types of perils that ancient travellers might have faced in their journey: attacks by pirates and bandits if travelling respectively by ship and on land..$^{19}$ The inclusion in the Digest of piracy and brigandage among common natural disasters affecting loans (along with the deaths

\footnotetext{
14 Sen. Cons. ad Helv. 19.4.

15 Sen. Cons. ad Helv. 19.5, 7.

16 S.B. Pomeroy, The Murder of Regilla: A Case of Domestic Violence in Antiquity (Cambridge, Mass. and London 2007), 121.

17 M. Carucci, 'Domestic violence in the Roman imperial society: giving voice to the abused women', forthcoming.

18 Pomeroy 2007, op. cit. (n. 16), 121.

19 B.D. Shaw, 'Bandits in the Roman Empire', Past \& Present 105 (1984), 3-52; L.H. Blumell, 'Beware of bandits! Banditry and land travel in the Roman Empire',Journeys 8 (2007), 1-20.
} 
of slaves, fires, shipwrecks, and slaves running away) ${ }^{20}$ and among common misfortunes (such as sickness, sea-storms, and winter weather) ${ }^{21}$ is an indication of their ubiquity and their occurrence during ancient travel, though Roman authors boasted of their eradication thanks to the pax Romana in the empire. Attacks by bandits also were listed as an example of common causes of death along with old age and sickness. ${ }^{22}$ The formulaic expression interfecta/ us a latronibus ("killed by bandits") that appears on a number of tombstones throughout the empire suggests that death due to bandits was a very frequent occurrence ${ }^{23}$ and a danger that may have affected women travellers, too. A badly preserved tombstone found in ancient Dacia was erected by the parents of a beloved daughter who had been killed by bandits. ${ }^{24}$ In a more detailed funerary inscription from Spalato, Iulius Restutus and Statia Pudentilla commemorate their infelicissima daughter Iulia Restuta who has been killed causa ornamentorum ("because of her jewellery"). ${ }^{25}$ The risk of attracting unwanted attention from bandits through the display of jewellery is also mentioned in a private letter dated to 296, in which Paniskos asks his wife Ploutegenia to visit him in Koptos:

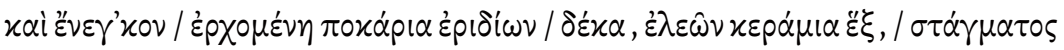

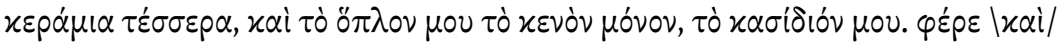

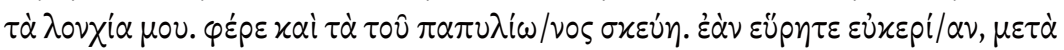

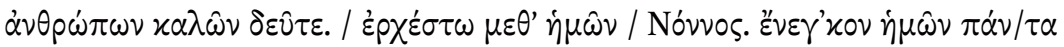

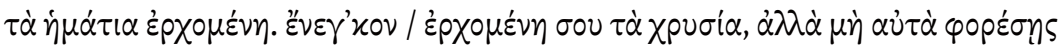
$\dot{\varepsilon} \nu \tau \hat{\omega} \pi \lambda o^{\prime} \omega$.

And when you come, bring ten fleeces of wool, six jars of olives, four jars of honeyed wine, and my shield - only the new one - and my helmet. Bring also my lances. Bring also the fittings of the tent. If you find an opportunity, come here with good men. Let Nonnos come with you. Bring

\footnotetext{
$20 \quad$ Dig. 13.6.18.pr.

21 Dig. 27.1.13.7.

22 Dig.13.6.5.4.

23 See, for instance, CIL 2. 1389, 2968, 3479 (Hispania); CIL 3. 1559, 1579 (Dacia); CIL 3. 2544, 8830 (Dalmatia); CIL 6. 234, 20307a (Rome); CIL 13. 259, 2282, 2667, 3689, 6429 (Germania). References to banditry in the Roman imperial times also occur in literary texts, such as the novel Leucippe and Clitophon by Achilles Tatius (5.7) and in the Metamorphoses by Apuleius $(1.7,15,23 ; 3.28 ; 4.6-22 ; 7.4,12,13 ; 8.15,17-18)$. See also Joh. Chrys. De virg. 24.2.

24 CIL 3.1585.

25 CIL 3. 2399.
} 
all our clothes with you when you come. Bring your gold ornaments with you on the trip, but do not wear them on the boat. ${ }^{26}$

This letter seems to suggest that a woman may be safe on travel, if she is accompanied by good and trustworthy men and does not openly display her jewellery on the way.

A small number of epitaphs collected in the Carmina Latina Epigraphica lament the fatal destiny of some women who died during their journeys, but the cause of their death is not mentioned. Antonia from Mauretania, piissima, dulcissima, rarissima, castissima and amantissima wife of the infelicissimus Titus Claudius Speratus, as it is recorded in the praescriptum, died in Italy while she was accompanying her husband: "The Italic land snatched me away with cruel death, while constantly assisting and serving my husband."27 A further epitaph found at Byzacium, in Africa, records the death of Urbanilla at Carthage while going back home with her husband Lucius:

Urbanilla mihi coniunx verecundia plena hic sita est / Romae comes negotiorum socia parsimonio fulta / bene gestis omnibus cum in patria mecum rediret / au miseram Carthago mihi eripuit sociam / nulla spes vivendi mihi sine coniuge tali / illa domum servare meam illa et consilio iuvare / luce privata misera qu(i)escit in marmore clusa / Lucius ego coniunx hic te marmore texi / (h)anc nobis sorted dedit fatu(m) cum luci daremur

Urbanilla my wife in her full modesty lies here. In Rome she was my supportive partner and associate in business. While she was going back home after a good business had been made, ah Carthago snatched my wretched companion away from me. No hope for me to live without such a wife: she looked after my house and assisted me with her advice. Deprived of light, the wretched woman rests inside a stone. I Lucius your husband buried you in this stone. We were given this fate when we were born. ${ }^{28}$

26 P. Mich. 2. 214; translation adapted from J. Rowlandson, ed., Women and Society in Greek and Roman Egypt: A Sourcebook (Cambridge 1998), 148. This document, which was found in the Fayum, is part of a group of letters exchanged between Paniskos and Ploutogenia.

27 CIL 6. 12056 = CLE 1026: Itala me rapuit crudeli funere tellus, / dum foveo assidua sedulitate virum. M. Arena and I. Bitto, 'Il motivo della morte in terra straniera nei CLE bücheleriani', in A. Akerraz, P. Ruggeri, A.Siraj, and C.Vismara, eds., L'Africa romana XVI, Rabat 2004 (Roma 2006), 1036.

$28 \quad C I L$ 8.152 = CLE 516; Arena and Bitto 2006, op. cit. (n. 27), 1037. 
We may suppose that Lucius was a merchant or involved in some business that he carried on together with his wife; on one of their business trips, Urbanilla died in circumstances that are not mentioned in the carmen. A short epitaph found in Ferentillum, in Etruria, mentions Chreste, a wet-nurse who died while accompanying the dedicators of her tumulus from Libya:

Chreste nutric[i fecimus] / hunc tum[ulum] / occidit haec Liby[ae terrae] / nos grandis a[b ora] / per freta per terr[as sedula] / dum sequ[itur] / corpus habet tellu[s et condita] / membra sed illinc.

We have made for Chreste our wet-nurse this barrow. She died on the wide Libyan shores while she was diligently following us by land and sea. The land has her body and pale limbs, but on that side. ${ }^{29}$

The poem ends with the motif of the individual buried in a foreign country that frequently occurs in funerary inscriptions. ${ }^{30}$

\section{Gendered Travel Risks}

The analysis of literary and epigraphical evidence highlights the most common dangers that ancient Roman women might have encountered in their travels. Nevertheless, the ancient record leaves us with the impression that there was no specifically gendered travel risk. Shipwreck, banditry, murder, and illness are the types of dangers that may have affected everyone on a journey in the Roman empire, regardless of their social status, age, provenance, or gender. What seem more specifically related to gender are rather the conditions of and reasons for travel. ${ }^{31}$

Travel was certainly more difficult and risky for a woman who was pregnant or accompanied by small children. Tacitus recounts that Zenobia was pregnant when she was forced to flee along with her husband Rhadamistus after his failed attempt at invading Armenia in AD 55:

Sed coniunx gravida primam utcumque fugam ob metum hostilem et mariti caritatem toleravit; post festinatione continua, ubi quati uterus

29 CLE 1845 = CIL 11.4991; Arena and Bitto 2006, op. cit. (n. 27), 1040.

30 Tybout 2016, op. cit. (n. 12).

31 For a discussion of the nature of female mobility specifically in Roman Egypt, see Foubert 2016, op. cit. (n. 2 ). 
et viscera vibrantur, orare ut morte honesta contumeliis captivitatis eximeretur.

But his wife, who was pregnant, endured in one way or the other the first part of the flight out of fear of the enemy and love for her husband; after a while, when she felt as if her womb and viscera were shaken by the continuous speed, she implored to be rescued from the shame of captivity by an honourable death. ${ }^{32}$

Urged by the intensity of his love, Rhadamistus agreed to listen to her prayers: he stabbed his wife and consigned her to the nearby river. While he hurried to his native kingdom of Iberia, Zenobia was noticed by some shepherds in a quiet backwater, still breathing and showing signs of life; she was then carried to the city of Artaxata, whence she was conducted to the King of Armenia, Tiridates, who received her kindly and treated her as a royal person. ${ }^{33}$

Iulia Maior probably gave birth to Agrippina Maior and perhaps also to Iulia Minor during her husband Agrippa's campaign in Asia minor; she was at Aquileia when she delivered a child fathered by Tiberius. ${ }^{34}$ Agrippina Maior gave birth to Agrippina Minor and Livilla while travelling with Germanicus; she also gave birth to her last daughter Iulia at Lesbos. ${ }^{35}$ In Tacitus' narrative, Agrippina Maior is portrayed as an active 'travelling wife' who accompanied her husband abroad during his military campaigns in Germania (AD 14) and in the east (AD 18). Travelling with her husband on several of his journeys in the provinces, however, proved to be very difficult and risky for Agrippina as a woman and as wife of a commander. When a mutiny broke out among the German legions, Agrippina had to flee together with her two-year-old son Caligula and a throng of upper-class women, wives of Germanicus' friends, who Tacitus describes as weeping round her. ${ }^{36}$ When Germanicus died in Antioch in 19 AD, Agrippina sailed back to Rome. In a few lines Tacitus portrays this young woman of the highest nobility who was usually praised for her splendid marriage, departing together with her little children and the ashes of her husband

32 Tac. Ann. 12.51.

33 As Tacitus does not make any further mention of the child that Zenobia was carrying, we may conclude that the difficulties of the journey and the stab caused a miscarriage. However, Zenobia and her possible child's later life is not recorded in any ancient textual source.

This child died almost immediately (Suet. Tib. 7).

35 Tac. Ann. 2.54.1.

36 Tac. Ann. 1.40.1. 
while worn out with grief and physically ill: "uncertain of her vengeance, apprehensive for herself, and at fortune's mercy by reason of the ill-starred fruitfulness of her marriage." ${ }^{37}$ Agrippina's return to Rome was not easy, either. Tacitus reports that on her way back to Italy, her ship was met by a squadron commanded by Piso ${ }^{38}$ that was skirting the coast of Lycia and Pamphilia. On each side the hostility was such that at first they prepared for action: then, owing to their mutual fears, the affair went no further than high words. ${ }^{39}$

In a private letter dated to the second century AD, Eutycheis writes to her mother Ametrion that her plan to visit her in Oxyrhynchus has been delayed by the lack of any suitable means of transport. ${ }^{40}$ For some unspecified reason, the camel drivers refused to make the trip; next she planned to travel by boat from Antinoopolis but could not find any boat available for that trip; she decided then to stay at Antinoopolis until a suitable vessel appeared and she could sail down. In the meantime Eutycheis instructed her mother to pay the men who delivered this letter to her. It is not clear how these men were able to travel to Oxyrhynchus. Was Eutycheis refused as a passenger either by camel or boat because of her gender? Or were there disturbances and fights in the region that made travelling more difficult for a woman?

The very brief references to women's journeys in both the epigraphical and literary record are undoubtedly influenced by the gendered ideologies of its male authors. What is missing is a sense of women's agency in their travels. Did Roman women want to travel? Were they happy to accompany their husbands in their military or business travels? What risks did they perceive in association with travel? What were the effects of their perceived travel risks? What strategies did they use to minimise risks? Written accounts of travels by Roman women would have certainly helped us answer those questions and could have provided an alternate view to male-authored narrative. Unfortunately, the corpus of literary works from the early empire includes only a very few

37 Tac. Ann. 2.75.1: incerta ultionis, anxia sui et infelici fecunditate fortunae totiens obnoxia.

38 Gnaeus Calpurnius Piso was appointed by Tiberius as governor of Syria in AD 17, apparently with secret instructions to thwart and control Germanicus, to whom the Eastern provinces had been assigned.

$40 \quad$ P. Oxy. 14. 1773; Bagnall and Cribiore 20o6, op. cit. (n. 10), 371-372. The papyrus was found at Antinoopolis. 
records written by women about their travels. ${ }^{41}$ In Elegy 3.14, Sulpicia ${ }^{42}$ mentions a possible journey to the country where her uncle Messalla is planning to celebrate her birthday, but the visit appeared later to have been cancelled (Elegy 3.15). During her tour to Egypt in the retinue of the emperor Hadrian and his wife, Terentia ${ }^{43}$ left record of her visit in a poem commemorating her deceased brother which was found inscribed on the surface of a pyramid near Memphis. However, it was only in the late eighteenth century that European women began to publish more comprehensive accounts of their travels in everincreasing numbers. Their writings show unmistakably how gender affects the way women experience and portray travel. ${ }^{44}$ Roman female-authored travelogue would also have given us a deeper glimpse into Roman women's experience of and approach to the perils of travel.

\section{$5 \quad$ Conclusions}

As mentioned at the beginning of this article, ancient ideology saw a close connection between women and domesticity. The idea that the natural place for women and femininity was to be found within the domestic world of house and family is expressed in a number of Roman writings. For example, in a funerary epitaph from Rome, Amymone, wife of Marcus, is praised for being lanifica, pia, pudica, frugi, casta, and domiseda ("a woolworker, dutiful, modest, temperate, chaste, and one who stays at home"). ${ }^{45}$ Another funerary inscription from the African town of Mactar commemorates a wife and mother nihil potius cupiens quam ut sua gauderet domus ("who desired nothing more than to rejoice her house"). ${ }^{46}$ In the male ideology, being away from the male-controlled domestic sphere could have exposed a woman to the danger of moral corruption. In Elegy 1.11, Propertius fears that Cynthia's journey to Baiae in the Bay of Naples may distract his mistress from her love for the poet, since the town was notorious

41 For a discussion of the literary and learning activities of ancient Roman women, see E.A. Hemelrijk, Matrona Docta. Educated Women in the Roman Elite from Cornelia to Julia Domna (London and New York 1999).

42 Hemelrijk 1999, op. cit. (n. 41), 148-154. Originally included in the Corpus Tibullianum, Sulpicia's poems were attributed to Tibullus, but this view has been challenged by more recent scholarship.

43 Hemelrijk 1999, op. cit. (n. 41), 164-167.

44 See contributions in K. Siegel, ed., Gender, Genre, and Identity in Women's Travel Writing (New York 2004).

$45 \quad C I L 6.11602$.

$46 \quad C I L$ 8.647. 
for licentious behaviour, ${ }^{47}$ while he is happy when Cynthia goes to remote places where no young man can seduce her. ${ }^{48}$ However, as Caecina claims in his speech to the Senate, even in the highly masculine military communities, women would have found an opportunity for intrigues and corrupt behaviour.

In his analysis of female mobility in the Roman West, Greg Woolf makes use of the concept of "social caging" to which ancient women were subject, to support his two main arguments: Roman women's opportunities for moving out of the communities in which they had been born, were very limited and, when they did travel, it was to accompany a male member of their family or their owner, if slaves. ${ }^{49}$ The textual evidence discussed above seems to partly support Woolf's second argument: when women travelled, they did so as wives (Seneca's aunt, Regilla, Antonia, Urbanilla, Zenobia), sisters (Septimius Severus' sister, see below), mothers (Monica), or slaves of a man (perhaps the wet-nurse Chreste). Roman women may also have travelled in the company of (male) servants or hired protectors. As Tacitus suggests in his description of the mutiny of the German legions that forced Agrippina to flee the fort, a centurion or a soldier for protection was part of the customary retinue that accompanied high-status women. ${ }^{50}$ The rhetoric of safety and morality that seems so intimately connected to women's mobility is still embedded in contemporary discourse on solitary women travellers. ${ }^{51} \mathrm{~A}$ woman who embarks on a journey without being escorted by a husband or another appropriate male companion is very likely to be perceived as making herself vulnerable to harassment and other male attacks that put at risk not only her safety but also her morality.

Nevertheless, for some journeys, women may have travelled without any male relative as an escort. In a second- or third-century private letter found in the Arsinoite nome, Thermouthas and Valeria write about their hope to sail downriver to their brother Apollinarios along with Demetrous and her (sc. Demetrous') mother, once Herois has given birth. ${ }^{52}$ In a funerary epigram found in Klaudioupolis, Longinus commemorates his wife Chrysopolis, an

47 Ov. Ars 1.255; Sen. Ep. 51.3. For a different experience of a woman's sojourn in Campania, see Plin. Ep. 6.4. His wife Calpurnia moved temporarily to the Bay of Naples to recover from her illness, while Pliny stayed at Rome to carry on his political affairs.

48 Prop. 2.19.

49 Woolf 2013, op. cit. (n. 2).

$50 \quad$ Tac. Ann. 1.41.

51 K. Siegel, 'Women's travel and the rhetoric of peril: it is suicide to be abroad', in idem 2004, op. cit. (n. 44), 55-72.

$5^{2} \quad B G U$ 1. 261; Bagnall and Cribiore 2006, op. cit. (n. 10), 189-190. The kind of relationships between the women mentioned in the letter are not clear. 
actress who died from fever abroad, while her husband remained at home. ${ }^{53}$ These examples warn us against the easy assumption that Roman women were necessarily accompanying a male member of their family when there is no mention of that. For example, Cornelia Tyche and her daughter Iulia Secunda, Aphrodite, Iulia Restuta, and Eutycheis do not seem to have travelled with any of their male relatives. ${ }^{54}$

The other argument discussed by Woolf, that particular social configurations of social power limited female mobility, seems not to be applicable to all types of ancient mobility, since it is restricted to specific forms of migration, such as military service, manual labour in the larger cities, and commercial activities. In these types of migration, clearly male migrants tended to outnumber women. If, by contrast, we use the term mobility in a wider sense encompassing all forms of moves, we may argue that female mobility was a much wider phenomenon. Furthermore, since Roman women were portrayed in light of social norms and ideals that associated them with home (as especially evident in funerary inscriptions), it could be argued that the lack of mention of travel in the textual references to women does not necessarily mean that they did not embark on any journey during their lifetime.

As ancient evidence shows, the Roman male ideal of the woman as domiseda was not always reflected in the practice of everyday life: a man embarking on a journey for any reason (e.g. political activities, military service, or commercial affairs) often was accompanied by female members of his family as part of the domestic functions that they were expected to perform in their role as good mothers, sisters, wives, or daughters. However, this dominant male ideology with regard to female conduct often also exposed ancient women to risks. Urbanilla died while accompanying her husband in his commercial affairs; Chreste died and was buried in a foreign country; similarly Monica died on her journey back to Africa, while supporting her son Augustine's decision to return home after his travels in Italy; ${ }^{55}$ Ploutogenia was asked to embark on a dangerous journey to join her husband; Agrippina Maior and Zenobia had to follow their husband in their political and military activities in troubled areas. Sometimes the hardships that women suffered travelling for men were more emotional than physical. Septimius Severus' sister came to Rome from Leptis to meet her brother, but she was hurriedly sent back home because her

SGO 09/09/o7; Tacoma and Tybout 2016, op. cit. (n. 2), 362. Chrysopolis may have travelled with a troop of actors.

54 More examples are mentioned by Foubert 2016, op. cit. (n. 2), 362.

55 It was Augustine who wished to return home after his travels in Italy, that was not his mother's own decision. 
inability to speak Latin embarrassed the emperor. ${ }^{56}$ The male-authored text, however, does not reflect on the feelings of Severus' sister: was she, too, embarrassed or was she ashamed of her brother's manners? The brief mention about the number of gifts that Severus gave to his sister before sending her home seems to suggest a feeling of guilt on the part of the emperor.

Caecina did not allow his wife to accompany him in the 40 campaigns that he had served in several provinces, ${ }^{57}$ because the senator regarded women as lacking physical or mental power to face the hardships involved in travel. However, in spite of Caecina's argument, textual evidence for female mobility in the Roman empire shows that women were capable of embarking on a journey with its all difficulties and uncertainties while still keeping their morality and gendered social identity intact.

Cardiff, November 2015

$56 \quad$ HA Sept. Sev. 1.15 .

57 In Caecina's scanty reference to his unnamed wife, it seems that this woman, who had borne her husband six children, had never left Italy. 